\title{
Charles Darwin and the Origin of Life
}

\author{
Juli Peretó • Jeffrey L. Bada • Antonio Lazcano
}

Received: 25 June 2009 / Accepted: 9 July 2009 /

Published online: 25 July 2009

(C) The Author(s) 2009. This article is published with open access at Springerlink.com

\begin{abstract}
When Charles Darwin published The Origin of Species 150 years ago he consciously avoided discussing the origin of life. However, analysis of some other texts written by Darwin, and of the correspondence he exchanged with friends and colleagues demonstrates that he took for granted the possibility of a natural emergence of the first life forms. As shown by notes from the pages he excised from his private notebooks, as early as 1837 Darwin was convinced that "the intimate relation of Life with laws of chemical combination, \& the universality of latter render spontaneous generation not improbable". Like many of his contemporaries, Darwin rejected the idea that putrefaction of preexisting organic compounds could lead to the appearance of organisms. Although he favored the possibility that life could appear by natural processes from simple inorganic compounds, his reluctance to discuss the issue resulted from his recognition that at the time it was possible to undertake the experimental study of the emergence of life.
\end{abstract}

Keywords Darwin $\cdot$ Warm little pond $\cdot$ Origin of life $\cdot$ Spontaneous generation

\section{Introduction}

What did Darwin think about the origin of life? His opinion seems to have changed over time from his original remark in the 1861 3rd edition of The Origin of Species «...it is no

Invited Paper

J. Peretó

Institut Cavanilles de Biodiversitat i Biologia Evolutiva and Departament de Bioquímica i Biologia

Molecular, Universitat de València, Apartat Postal 22085, 46071 València, Spain

J. L. Bada

Scripps Institution of Oceanography, University of California at San Diego, La Jolla, CA 92093-0212, USA

A. Lazcano $(\square)$

Facultad de Ciencias, UNAM, Apdo. Postal 70-407, Cd. Universitaria, 04510 Mexico D.F., Mexico e-mail: alar@correo.unam.mx 
valid objection that science as yet throws no light on the far higher problem of the essence or origin of life», which he reiterated in a letter he mailed to his close friend Joseph Dalton Hooker on March 29, 1863, in which he wrote that «...it is mere rubbish thinking, at present, of origin of life; one might as well think of origin of matter». But yet, in a now famous paragraph in the letter sent to the same addressee on February 1st, 1871, he stated that «it is often said that all the conditions for the first production of a living being are now present, which could ever have been present. But if (and oh what a big if) we could conceive in some warm little pond with all sort of ammonia and phosphoric salts,- - light, heat, electricity present, that a protein compound was chemically formed, ready to undergo still more complex changes, at the present such matter would be instantly devoured, or absorbed, which would not have been the case before living creatures were formed [...]».

Darwin's opinions on the origin of the first organisms thus varied somewhat during his life, but never lead to the dramatic shift that could be implied by reading only the two paragraphs included. Indeed, a careful examination and critical reading of his public and private writings shows that what appear to be contradictory opinions on the problem of the emergence of life are the result of texts read out of context, sometimes maliciously, as shown by some publications of creationist groups and advocates of the so-called intelligent design.

Darwin was a meticulous writer who kept detailed diaries and excellent records of his extensive correspondence. This allows a detailed examination of the development of his ideas, a task facilitated not only by examining the books and articles he published during his lifetime, but also by the online availability of his correspondence and notebooks, including the pages that Darwin himself excised from them but which have survived.

Any attempt to study in detail Darwin's ideas on the origin of life must consider the work of Farley (1977) and Strick (2000). Our own analysis has been greatly facilitated by the detailed cross-references and bibliographical analyses available at The Darwin Correspondence Project (Jim Secord, http:/www.darwinproject.ac.uk/) and The Complete Work of Charles Darwin Online (John van Wyhe, http://darwin-online.org.uk/). What we report here is not an exhaustive examination of all the phrases, sentences, letters or paragraphs in which Darwin touched in one way or another on the problem of the origins of life, or related issues like spontaneous generation or archebiosis. We have not included, for instance, his epistolary exchanges with W. H. Dallinger or his extensive correspondence with John Tyndall, in which the later described his efforts to study spontaneous generation. Some original material was unavailable to us, and it is likely that in the future more letters and notes will be discovered. However, what is available demonstrates that for Charles Darwin the origin of life was an issue that could be analyzed scientifically, even if he recognized that the times were not ripe for doing so.

\section{The Appearance of Life and the Origin of Species: Two Separate Issues}

«The chief defect of the Darwinian theory is that it throws no light on the origin of the primitive organism - probably a simple cell — from which all the others have descended. When Darwin assumes a special creative act for this first species, he is not consistent, and, I think, not quite sincere...» wrote Haeckel in 1862 in a footnote in his monograph on the radiolaria (Haeckel 1862). His criticism was accurate but surprising, given the boundless admiration that he had for Darwin. Haeckel was not alone in raising the issue. When the German geologist Heinrich George Bronn, translated The Origin of Species, in 1860, he did not hesitate to add a chapter of his own in which he discussed spontaneous generation in the context of Darwin's theory. That very same year Bronn published an essay in which he 
argued quite emphatically that Darwin's theory was incomplete until it could account for the origin of life, adding that some observations by Priestley, Pouchet and others could provide an example of spontaneous generation.

Darwin did not take exception to Haeckel's remarks, nor was he impressed by Bronn's criticisms. On February 16, 1860 he mailed to Lyell his own copy of Bronn's Jahrbuch fur Mineralogie, and wrote that [www.darwinproject.ac.uk/] [Letter 2703]:

«The united intellect of my family has vainly tried to make it out-I never tried such confoundedly hard German: nor does it seem worth the labour,- - He sticks to Priestley's green matter \& seems to think that till it can be shown how life arises, it is no good showing how the forms of life arise. This seems to me about as logical (comparing very great things with little) as to say it was no use in Newton showing laws of attraction of gravity \& consequent movements of the Planets, because he could not show what the attraction of Gravity is»).

Everything that is known about Darwin's personality suggests that he was sincerely uneasy comparing his work to Newton's. Nevertheless, in the 18613 rd edition of The Origin of Species, he pursued the analogy in order to underline the distinction between the origin and nature of life, and the understanding of the processes underlying its evolution: «I have now recapitulated the chief facts and considerations which have thoroughly convinced me that species have been modified, during a long course of descent, by the preservation or the natural selection of many successive slight favourable variations. I cannot believe that a false theory would explain, as it seems to me that the theory of natural selection does explain, the several large classes of facts above specified. It is no valid objection that science as yet throws no light on the far higher problem of the essence or origin of life. Who can explain what is the essence of the attraction of gravity? No one now objects to following out the results consequent on this unknown element of attraction; notwithstanding that Leibnitz formerly accused Newton of introducing "occult qualities and miracles into philosophy"» (Peckham 1959:748).

Darwin raised the issue again in 1868, when he published The Variation of Animals and Plants under Domestication. In this book he wrote «It is the consideration and explanation of such facts as these which has convinced me that the theory of descent with modification by means of natural selection is in the main true. These facts have as yet received no explanation on the theory of independent Creations; they cannot be grouped together under one point of view, but each has to be considered as an ultimate fact. As the first origin of life on this earth, as well as the continued life of each individual, is at present quite beyond the scope of science, I do not wish to lay much stress on the greater simplicity of the view of a few forms, or of only one form, having been originally created, instead of innumerable miraculous creations having been necessary at innumerable periods; though this more simple view accords well with Maupertuis's philosophical axiom 'of least action'» (Darwin 1868, Vol 1:12).

\section{Heterogenesis, Archebiosis and Spontaneous Generation: A Cautionary Note on Nomenclature}

Analysis of Darwin's views on the origin of life and those of his contemporaries must take into account that during the 19th century the usage of the term "spontaneous generation" was open to different interpretations. As underlined by Farley (1977), Strick (2000) and Raulin-Cerceau (2004), debates on the existence or denial of spontaneous generation included a major distinction between two largely forgotten terms, i.e., heterogenesis and 
archebiosis. According to Henry Charlton Bastian, one of the most prominent characters during the Victorian origin-of-life debates, archebiosis refers to the "origin of living things from not-living materials" whereas heterogenesis was "the possibility of living things arising by previously unknown methods from the matter of pre-existing living things", which could be decaying or not (Bastian 1907; Strick 2000).

Darwin read critically Bastian's 1872 book The Beginnings of Life. Although he was not convinced in full, he did accept the possibility of a natural origin of life from non-living matter, and wrote to Wallace [Letter 8488] (Strick 2000),

«My Dear Wallace,- - I have at last finished the gigantic job of reading Dr. Bastian's book and have been deeply interested by it. You wished to hear my impression, but it is not worth sending. He seems to me an extremely able man, as, indeed, I thought when I read his first essay. His general argument in favour of Archebiosis is wonderfully strong, though I cannot think much of some few of his arguments. The result is that I am bewildered and astonished by his statements, but am not convinced, though, on the whole, it seems to me probable that Archebiosis is true».

And he added, in a letter to Haeckel in 1872 [Letter 8506] (Strick 2000) that «[O]ur English Dr. Bastian has lately published a book on so-called Spontaneous Generation, which has perplexed me greatly. He has collected all the observations made by various naturalists, some of them good observers, on the protoplasm within the cells of dying plants and animals becoming converted into living organisms. He has also made many experiments with boiled infusions in closed flasks; but I believe he is not a very careful observer. Nevertheless, the general argument in favor of living forms being now produced under favorable conditions seems to me strong; but I can form no final conclusions».

Always the faithful friend and follower, in 1876 Haeckel mailed Darwin a copy of his recently published The History of Creation. Darwin wrote back thanking him but also viewed with caution Haeckel's endorsement of spontaneous generation (Darwin 1887, Vol 3:180),

«My dear Häckel,- - I thank you for the present of your book, and I am heartily glad to see its great success. You will do a wonderful amount of good in spreading the doctrine of Evolution, supporting it as you do by so many original observations. [...] I will at the same time send a paper which has interested me; it need not be returned. It contains a singular statement bearing on so-called Spontaneous Generation. I much wish that this latter question could be settled, but I see no prospect of it. If it could be proved true this would be most important to us [...].

Wishing you every success in your admirable labours,

I remain, my dear Häckel, yours very sincerely».

\section{Hiding Ideas in a Decaying Mass of Mud}

On March 28, 1863 the Athenæum, the very exclusive social club located at Carlton House Pall Mall London whose members included politicians, clergymen, gentlemen of fortune, journalists and naturalists, published an anonymous review of the Introduction to the Study of the Foraminifera that the distinguished physician and naturalist Walter Benjamin Carpenter had written the year before. That very same day Hooker mailed a copy to Darwin. The review was soon shown to have been written by Richard Owen, who argued in it that foraminifera and other microscopic organisms could periodically form spontaneously in mud due to an undefined "general polarizing force", and harshly criticized Darwin by stating that he "could only express" the creative force responsible for the origin of life "in Pentateuchal terms as the primordial form into which life was first breathed!". 
The next day Darwin sent a letter to Hooker thanking him for the copy of the Athenæum publication, and commented ironically on Owen's arguments [www.darwinproject.ac.uk/] [Letter 4065],

«[...] Many thanks for Athenæum, received this morning \& to be returned tomorrow morning. Who would have ever thought of the old stupid Athenæum taking to Oken-like transcendental philosophy written in Owenian style! It will be some time before we see "slime, snot or protoplasm" (what an elegant writer) generating a new animal. But I have long regretted that I truckled to public opinion \& used Pentateuchal term of creation, by which I really meant "appeared" by some wholly unknown process.-It is mere rubbish thinking, at present, of origin of life; one might as well think of origin of matter».

Three weeks later, Darwin (1863) finished a sharp response to Owen's criticism, and submitted it to the Athenæum, which promptly published it [www.darwinproject.ac.uk/] [Letter 4108]

«Down, Bromley, Kent, April 18.

I hope that you will permit me to add a few remarks on Heterogeny, as the old doctrine of spontaneous generation is now called, to those given by Dr. Carpenter, who, however, is probably better fitted to discuss the question than any other man in England. Your reviewer believes that certain lowly organized animals have been generated spontaneously - that is, without pre-existing parents_-during each geological period in slimy ooze. A mass of mud with matter decaying and undergoing complex chemical changes is a fine hiding-place for obscurity of ideas. But let us face the problem boldly. He who believes that organic beings have been produced during each geological period from dead matter must believe that the first being thus arose. There must have been a time when inorganic elements alone existed on our planet: let any assumptions be made, such as that the reeking atmosphere was charged with carbonic acid, nitrogenized compounds, phosphorus, \&c. Now is there a fact, or a shadow of a fact, supporting the belief that these elements, without the presence of any organic compounds, and acted on only by known forces, could produce a living creature? At present it is to us a result absolutely inconceivable. Your reviewer sneers with justice at my use of the "Pentateuchal terms", "of one primordial form into which life was first breathed": in a purely scientific work I ought perhaps not to have used such terms; but they well serve to confess that our ignorance is as profound on the origin of life as on the origin of force or matter. Your reviewer thinks that the weakness of my theory is demonstrated because existing Foraminifera are identical with those which lived at a very remote epoch. Most naturalists look at this fact as the simple result of descent by ordinary reproduction; in no way different, as Dr. Carpenter remarks, except in the line of descent being longer, from that of the many shells common to the middle Tertiary and existing periods.

The view given by me on the origin or derivation of species, whatever its weaknesses may be, connects (as has been candidly admitted by some of its opponents, such as Pictet, Bronn, \&c.) by an intelligible thread of reasoning a multitude of facts: such as the formation of domestic races by man's selection, - the classification and affinities of all organic beings, - the innumerable gradations in structure and instincts, - the similarity of pattern in the hand, wing or paddle of animals of the same great class, - the existence of organs become rudimentary by disuse, - the similarity of an embryonic reptile, bird and mammal, with the retention of traces of an apparatus fitted for aquatic respiration; the retention in the young calf of incisor teeth in the upper jaw, \&c., - the distribution of animals and plants, and their mutual affinities within the same region, - their general geological succession, and the close relationship of the fossils in closely consecutive formations and within the same country; extinct marsupials having preceded living marsupials in Australia, and armadillo-like animals having preceded and generated armadilloes in South America, - and many other phenomena, such as the gradual extinction of old forms and their gradual replacement by new forms better fitted for their new 
conditions in the struggle for life. When the advocate of Heterogeny can thus connect large classes of facts, and not until then, he will have respectful and patient listeners.

Dr. Carpenter seems to think that the fact of Foraminifera not having advanced in organization from an extremely remote epoch to the present day is a strong objection to the views maintained by me. But this objection is grounded on the belief - the prevalence of which seems due to the well-known doctrine of Lamarck - that there is some necessary law of advancement, against which view I have often protested. Animals may even become degraded, if their simplified structure remains well fitted for their habits of life, as we see in certain parasitic crustaceans. I have attempted to show (Origin, 3rd edit. p. 135) that lowlyorganized animals are best fitted for humble places in the economy of nature; that an infusorial animalcule or an intestinal worm, for instance, would not be benefited by acquiring a highly complex structure. Therefore, it does not seem to me an objection of any force that certain groups of animals, such as the Foraminifera, have not advanced in organization. Why certain whole classes, or certain numbers of a class, have advanced and others have not, we cannot even conjecture. But as we do not know under what forms or how life originated in this world, it would be rash to assert that even such lowly endowed animals as the Foraminifera, with their beautiful shells as figured by Dr. Carpenter, have not in any degree advanced in organization. So little do we know of the conditions of life all around us, that we cannot say why one native weed or insect swarms in numbers, and another closely allied weed or insect is rare. Is it then possible that we should understand why one group of beings has risen in the scale of life during the long lapse of time, and another group has remained stationary? Sir C. Lyell, who has given so excellent a discussion on species in his great work on the 'Antiquity of Man', has advanced a somewhat analogous objection, namely, that the mammals, such as seals or bats, which alone have been enabled to reach oceanic islands, have not been developed into various terrestrial forms, fitted to fill the unoccupied places in their new island-homes; but Sir Charles has partly answered his own objection. Certainly I never anticipated that I should have had to encounter objections on the score that organic beings have not undergone a greater amount of change than that stamped in plain letters on almost every line of their structure. I cannot here resist expressing my satisfaction that Sir Charles Lyell, to whom I have for so many years looked up as my master in geology, has said (2nd edit. p. 469):- "Yet we ought by no means to undervalue the importance of the step which will have been made, should it hereafter become the generally received opinion of men of science (as I fully expect it will) that the past changes of the organic world have been brought about by the subordinate agency of such causes as Variation and Natural Selection”. The whole subject of the gradual modification of species is only now opening out. There surely is a grand future for Natural History. Even the vital force may hereafter come within the grasp of modern science, its correlations with other forces have already been ably indicated by Dr. Carpenter in the Philosophical Transactions; but the nature of life will not be seized on by assuming that Foraminifera are periodically generated from slime or ooze.

Charles Darwin»

It is somewhat surprising to see that historians of science have largely overlooked Darwin's extensive response, which is the direct antecedent to the "warm little pond" letter that he sent in 1871 to Hooker. In any case, Darwin had enjoyed so much preparing his rebuttal of Owen, that two days later after mailing it to the Athenæum he wrote to Asa Gray that [www.darwinproject.ac.uk/] [Letter 4110],

«[...] We have had lately sharp sparring in the Athenæum. Did you see the article on Heterogeny or Spontaneous generation, written I believe, certainly by Owen!! it was in Review on Carpenter, who seems to have been sillily vexed at Owen calling me Carpenter's 
master; it was like his clever malignity. Under the cloak of a fling at Heterogeny I have sent a letter to Athenæum in defence of myself, \& I take sly advantage to quote Lyells amended verdict on the Origin.-I suppose my letter will appear next week: it is no great thing. [...]»

\section{The Story Behind a Warm Little Pond}

It is certainly amusing to see that Darwin did not refrain, both in private and in public, from the use of irony, as shown by the extensive letter he sent to the Athenæum. He clearly kept in the back of his mind his assumption that life could evolve from a «... reeking atmosphere was charged with carbonic acid, nitrogenized compounds, phosphorus, \&c.». Eight years later he mailed to Hooker the famous letter in which the idea of a "warm little pond" was included. Darwin's "big if", however, is a cautious reminder that he was keenly aware of the lack of evidence for this possibility. The now famous letter was mailed to Hooker on February 1st, 1871,

\section{«Down,}

Beckenham, Kent, S.E.

My dear Hooker,

I return the pamphlets, which I have been very glad to read.- It will be a curious discovery if Mr. Lowe's observation that boiling does not kill certain molds is proved true; but then how on earth is the absence of all living things in Pasteur's experiments to be accounted for?-I am always delighted to see a word in favour of Pangenesis, which some day, I believe, will have a resurrection. Mr. Dyer's paper strikes [?] me as a very able Spencieran production.

It is often said that all the conditions for the first production of a living organism are now present, which could ever have been present. But if (and oh what a big if) we could conceive in some warm little pond with all sorts of ammonia and phosphoric salts,- - light, heat, electricity \&c. present, that a protein compound was chemically formed, ready to undergo still more complex changes, at the present day such matter $\mathrm{w}^{\mathrm{d}}$ be instantly devoured, or absorbed, which would not have been the case before living creatures were formed.

Henrietta makes hardly any progress, and God knows when she will be well.

I enjoyed much the visit of you four gentlemen, i.e., after the Saturday night, when I thought I was quite done for.

Yours affect ${ }^{\mathrm{y}}$

C. Darwin»

His son Francis Darwin included part of this now famous letter as a footnote in the 3rd volume of Life and Letters (Darwin 1887, Vol 3:168-169). In 1969 Melvin Calvin included the letter (both the transcription and the facsimile) in his book on chemical evolution (Calvin 1969), calling it to the attention of the origins-of-life community.

Darwin's letter summarizes in a nutshell his ideas on the emergence of life, and provides insights on the views on the chemical nature of the basic biological processes that were becoming prevalent in scientific circles. Although Friedrich Miescher had discovered nucleic acids (he called them nuclein) in 1869 (Dahm 2005), the deciphering of their central role in genetic processes would remain unknown for almost another century. In contrast, the roles played by proteins in manifold biological processes had been established. Equally significant, by the time Darwin wrote his letter major advances had been made in the understanding of the material basis of life, which for a long time had been considered to be fundamentally different from inorganic compounds. Although in 1827 Jöns Jacob 
Berzelius, probably the most influential chemist of his day, had written that "art cannot combine the elements of inorganic matter in the manner of living nature", 1 year later his friend and former student Friedrich Wöhler demonstrated that urea could be formed in high yield by heating ammonium cyanate "without the need of an animal kidney".

Although Darwin had developed a strong interest in chemistry as a youngster, it is not known if he was aware of the synthesis of alanine achieved by Adolf Strecker in 1850. In the absence of any real corroborative evidence, it is impossible to guess what Darwin thought about the nature of the first living beings. In any case, Darwin's remarks should not be read to imply that he was thinking in terms of prebiotic chemistry, but rather that he recognized that the chemical gap separating organisms from the non-living was not insurmountable.

\section{Fossils in Meteorites: the Meeting that Never was}

In his recently published Charles Darwin Shorter Publications 1829-1883, van Wyhe (2009) has included a curious item published in 1881 in Science under the title Mr. Darwin on Dr. Hahn's discovery of fossil organisms in meteorites. The short note describes an exchange between Charles Darwin and Otto Hahn, an amateur geologist who claimed in 1880 that he had discovered remains of extraterrestrial sponges, corals and plants in the Knyahinya meteorite that fell in Hungary on June 6, 1866 (van Wyhe 2009). The complete text states that,

«Dr. Hahn's discovery, of which an elaborate account was given in No. 50 of SCIENCE has stirred up a lively discussion of this highly interesting subject. Dr. Hahn has taken steps to enable Prof. von Quenstedt, the renowned Tübingen geologist, and all others who expressed the desire to examine his microscopic preparations. It is understood that all those who have availed themselves of the opportunity thus offered have become convinced of the genuineness of Dr. Hahn's discovery.

It is very interesting to note the position taken by the greatest of living evolutionists in this controversy, if it can still be called such. Charles Darwin, on receipt of Dr. Hahn's work, wrote to him: “... It seems to be very difficult to doubt that your photographs exhibit organic structure..." and furthermore: "... your discovery is certainly one of the most important".

Not content with the mere presentation of his work, Dr. Hahn visited the veteran zoologist and brought his preparations to him for inspection.

No sooner had Mr. Darwin peered through the microscope on one of the finest specimens when he started up from his seat and exclaimed: "Almighty God! what a wonderful discovery! Wonderful!" And after a pause of silent reflection he added: "Now reaches life down!" The latter remark no doubt refers to the proof furnished by Dr. Hahn's discovery that organisms can reach our planet from celestial space. It is an acknowledgment of the relief Mr. Darwin must have felt in not being forced to a belief in a primeval "generatio equivoca".

As was suggested in the paper referred to, "the Richter-Thomson ["cosmozoa/ panspermia"]hypothesis of the origin of life on the earth has become a tangible reality!"»

Hahn's books are now at Down House but have no marginalia (van Wyhe 2009). Moreover, in the Darwin Archive (DAR251, calendar 12929f) there is draft of a letter that Darwin sent on December 20, 1880 to Hahn, in which he wrote that "If you succeed in convincing several judges as trustworthy as Professor Quenstedt, you will certainly have made one of the most remarkable discoveries ever recorded." However, there is no evidence 
that Hahn actually visited Down House, and this may be apocryphal. As described by van Wyhe (2009) "no evidence for the interview has been found in the Stadtsarchiv Reutlingen, Germany, in the Darwin Archive or in the correspondence". Thomas George Bonney (1833-1923), professor of geology at University College, London, wrote to Francis Darwin [January? 1882] (Cambridge University Library MSS.DAR.160:247) asking if the report in Science was true. Bonney intended to insert a rebuttal for the claim in a review he was writing (unidentified) on an allied subject. Darwin replied in a letter to Bonney (now lost). Bonney later thanked Darwin in a 5 February 1882 letter (Cambridge University Library MSS.DAR.160:246 and 248) for denying the truth of the claim that he accepted the organic nature of the microscopic structures and remarked that "Hahn could not distinguish between mineral and organic structures". In fact, it is likely that Hahn's visit never took place.

It should be noted that because of William Thomson's (later Lord Kelvin) claim that the Earth's age was too young to be compatible with Darwin's theory of evolution, and Pasteur's work debunking spontaneous generation, the "cosmozoa/panspermia" theory was championed by many noted scientists during Darwin's time, although apparently he never commented on the concept. The idea that there were fossils present in some meteorites was embraced by parts of the scientific community although others questioned the validity of these claims. As Hooker wrote, "[t]he notion of introducing life on Meteors is astounding and very unphilosophical [...]. For my part, I would as soon believe in the Phoenix as in the meteoritic import of life" (Hooker 1871, in Crowe 1986).

\section{Final Remarks}

Although Darwin had stated in The Origin of Species that "all the organic beings which have ever lived on this Earth may be descended from some primordial form", he was keenly aware that there was no explanation of how such an ancestral entity had first evolved. Darwin's theory was based, among other lines of evidence, on observations of living and fossil organisms, but for him the fossil record stopped at rocks that we know now correspond to the end of the Precambrian. Moreover, he did not view microbes, which are gorgeously absent from his work, as evolutionary predecessors of animals and plants (Lazcano 2002). Charles Darwin's self-imposed task was the understanding of the evolutionary processes that underlie biological diversity, a task that epistemologically can be undertaken even if it provides no explanation of the origin of life itself. As he wrote in 1839 in his Fourth Notebook (de Beer 1960:180), «My theory leaves quite untouched the question of spontaneous generation».

Darwin included few statements on the origin of life in his books. As underlined by Aulie (1970) this is what he wanted to make public. Over and over again he carefully emphasized the lack of evidence on the possibility of spontaneous generation. For instance, in the 6th edition of The Origin of Species (1871) he stated «...it may be objected that if all organic beings thus tend to rise in the scale, how is it that throughout the world multitude of the lowest forms still exist [...]. Lamarck, who believed in an innate and inevitable tendency towards perfection in all organic beings, seems to have felt this difficulty so strongly, that he was led to suppose that new and simple forms were continually being produced by spontaneous generation. Science has not as yet proved the truth of this belief, whatever the future may reveal» (Peckham 1959:223).

Not surprisingly, the idea that living organisms were the historical outcome of gradual transformation of lifeless matter became widespread soon after the publication of Darwin's The Origin of Species. However, Darwin was not a prophet who predicted in his 1871 letter 
to Hooker the experiments on abiotic chemical synthesis carried out since the first 1953 Miller-Urey experiment. Although he insisted over and over again that there was no evidence of how the first organisms may have first appeared, he was firmly convinced it was the outcome of a natural process that had to be approached from a secular framework.

It is true, as Lady Antonia Fraser once wrote, that hindsight can make bad history. However, Darwin's reluctance to discuss the origin of life does not imply that he advocated mystical explanations. As shown by the pages that he would later excise from his Second Notebook, as early as 1837 he was convinced that "The intimate relation of Life with laws of chemical combination, \& the universality of latter render spontaneous generation not improbable." (de Beer et al. 1967).

This early statement is consistent with many other lines of evidence demonstrating that Darwin took for granted a natural origin of life. However, his ideas on how it may have happened must remain forever in the domain of historical speculation. In a letter he sent in February 28, 1882 to D. Mackintosh (Letter 13711, Cambridge University Library, DAR.146:335), he included an indirect reference to Wöhler's synthesis of urea and added that

«Though no evidence worth anything has as yet, in my opinion, been advanced in favour of a living being, being developed from inorganic matter, yet I cannot avoid believing the possibility of this will be proved some day in accordance with the law of continuity. I remember the time, above 50 years ago, when it was said that no substance found in a living plant or animal could be produced without the aid of vital forces. As far as external form is concerned, Eozoon shows how difficult it is to distinguish between organised and inorganised bodies. If it is ever found that life can originate on this world, the vital phenomena will come under some general law of nature. Whether the existence of a conscious God can be proved from the existence of the so called laws of nature (i. e. fixed sequence of events) is a perplexing subject, on which I have often thought, but cannot see my way clearly...».

Over and over again Darwin insisted that the issue of spontaneous generation was intractable by the science of his time. As he wrote on November 21, 1866 to Julius Viktor Carus [www.darwinproject.ac.uk/] [Letter 5282], who was preparing a new edition of The Origin of Species, that,

«My dear Sir

[...] I see that I have forgotten to say that you have my fullest consent to append any discussion which you may think fit to the new edition. As for myself I cannot believe in spontaneous generation \& though I expect that at some future time the principle of life will be rendered intelligible, at present it seems to me beyond the confines of science».

He was to maintain the same attitude for many years to come, as shown by the letter mailed on March 28, 1882, near the end of his life, to George Charles Wallich (de Beer 1959). In it Darwin wrote that,

«My dear Sir,

You expressed quite correctly my views where you say that I had intentionally left the question of the Origin of Life uncanvassed as being altogether ultra vires in the present state of our knowledge, \& that I dealt only with the manner of succession. I have met with no evidence that seems in the least trustworthy, in favour of the so-called Spontaneous generation. I believe that I have somewhere said (but cannot find the passage) that the principle of continuity renders it probable that the principle of life will hereafter be shown to be a part, or consequence of some general law; but this is only conjecture and not science. I know nothing about the Protista, and shall be very glad to read your Lecture when it is published, if you will be so kind as to send me a copy. 
I remain, my dear Sir,

Yours very faithfully

\section{Charles Darwin»}

Darwin's letter to Wallich expresses once more his reaction against the idea of life emerging from the decomposition of organic compounds. It is interesting, however, to recall a letter he sent on August 28, 1872 to Wallace, were Darwin wrote that ([Letter 8488],

«[...] I should like to live to see Archebiosis proved true, for it would be a discovery of transcendent importance; or, if false, I should like to see it disproved, and the facts otherwise explained; but I shall not live to see all this». Nor will we.

Acknowledgements The assistance of Mr. Adam Perkins, archivist of the Darwin Archive at Cambridge University Library and Mme. Judith Magee, Collection Development Manager of the Natural History Museum Library is gratefully acknowledged. The authors also wish to thank Paola Marco for her help to localize some of Darwin's letters. The work reported here has been greatly facilitated by the documents available at The Darwin Correspondence Project (http://www.darwinproject.ac.uk/, Jim Secord, director) and The Complete Work of Charles Darwin Online (http://darwin-online.org.uk/, John van Wyhe, director). J.P. acknowledges the financial support by grants BFU2006-01951/BMC from the Spanish Ministry of Science and Innovation and FP7-KBBE-2007-212894 (TARPOL project, European Union). The support of the Institut Pasteur-Fondazione Cenci Bolognetti (Universita di Roma, La Sapienza) and the generous hospitality of Professor Ernesto di Mauro (Universita di Roma, La Sapienza) to A.L. are gratefully acknowledged.

Open Access This article is distributed under the terms of the Creative Commons Attribution Noncommercial License which permits any noncommercial use, distribution, and reproduction in any medium, provided the original author(s) and source are credited.

\section{References}

Aulie R (1970) Darwin and spontaneous generation. J Amer Sci Affil 22:31-33

Bastian HC (1907) The evolution of life. P. Dutton and Co, New York

Bronn HG (1860) [Review of] Ch. Darwin: on the origin of species by means of natural selection, or the preservation of favoured races in the struggle for life (London 1859). Neues Jahrbuch für Mineralogie, Geognosie, Geologie und Petrefaktenkunde:112-116 [Translated in David Hull, 1973. Darwin and His Critics: The Reception of Darwin's Theory of Evolution by the Scientific Community. University of Chicago Press, Chicago pp. 120-124]

Calvin M (1969) Chemical evolution: Molecular evolution towards the origin of living systems on the Earth and elsewhere. Oxford University Press, New York

Crowe MJ (1986) The extraterrestrial life debate 1750-1900: The idea of a plurality of worlds from Kant to Lowell. Cambridge University Press, Cambridge

Dahm R (2005) Friedrich Miescher and the discovery of DNA. Dev Biol 278:274-288

Darwin Ch (1863) The doctrine of heterogeny and modification of species. Athenæum no. 1852, 25 April 1863:554-555. [Reprinted in: van Wyhe J 2009:334-337]

Darwin Ch (1868) The variation of animals and plants under domestication, 2 vols. Murray, London

Darwin F (ed) (1887) The life and letters of Charles Darwin, including an autobiographical chapter, 3 vols. John Murray, London

De Beer G (1959) Some unpublished letters of Charles Darwin. Notes Rec R Soc Lond 14:12-66

de Beer G (ed) (1960) Darwin's notebooks on transmutation of species. Part IV, Fourth notebook [E] (October 1838-10 July 1839). Bull Brit Mus (Nat Hist) Hist Ser 2: 151-183

de Beer G, Rowlands MJ, Skramovsky BM (eds) (1967) Darwin's notebooks on transmutation of species. Part VI. Pages excised by Darwin. Bull Brit Mus (Nat Hist) Hist Ser 3:129-176

Farley J (1977) The spontaneous generation controversy: from Descartes to Oparin. Johns Hopkins University Press, Baltimore

Haeckel E (1862) Die Radiolarien (Rhizopoda Radiaria). Eine Monographie. Druck und Verlag Von Georg Reimer, Berlin 
Lazcano A (2002) Foreword to Lynn Margulis and Michael Dolan's early life. Jones \& Bartlett, Boston, pp xvii-xx

Peckham M (1959) The origin of species. A variorum text. University of Pennsylvania Press, Philadelphia Raulin-Cerceau F (2004) Historical review of the origin of life and astrobiology. In: Seckbach J (ed) Origins. Kluwer Academic Press, Dordrecht, pp 15-33

Strick JE (2000) Sparks of life. Darwinism and the Victorian debates over spontaneous generation. Harvard University Press, Cambridge

van Wyhe J (ed) (2009) Charles Darwin shorter publications 1829-1883. Cambridge University Press, Cambridge 